\title{
Anatomy description of cervical region and hyoid apparatus in living giant anteaters Myrmecophaga tridactyla Linnaeus, 1758 $^{1}$
}

\author{
Naida C. Borges ${ }^{2 *}$, João R.B. Nardotto ${ }^{3}$, Raquel S.L. Oliveira², Larissa H.E. Rüncos ${ }^{4}$, \\ Rejane G. Ribeiro ${ }^{5}$ and Andria M. Bogoevich ${ }^{6}$
}

\begin{abstract}
Borges N.C., Nardotto J.R.B., Oliveira R.S.L., Rüncos L.H.E., Ribeiro R.G. \& Bogoevich A.M. 2017. Anatomy description of cervical region and hyoid apparatus in living giant anteaters Myrmecophaga tridactyla Linnaeus, 1758. Pesquisa Veterinária Brasileira 37(11):1345-1351. Setor de Diagnóstico por Imagem, Escola de Veterinária e Zootecnia, Universidade Federal de Goiás, Campus Samambaia, Cx. Postal 131, Goiânia, GO 74001970, Brazil. E-mail: naidaborges@yahoo.com.br

The giant anteater has specific anatomical adaptations resulting from its ant and termite feeding habits. The unique arrangement of its hyoid apparatus is essential for the ingestion of food. However, its description in the literature is based on fragments and fossils, making it difficult to determine existing anatomical details in live animals. Imaging techniques, which enable the topographical anatomy of animals to be examined noninvasively, provide essential information for the diagnosis and prognosis of diseases. The aim of this study is to describe the bone contours in the hyoid apparatus of the giant anteater by means of radiographic and tomographic images. Giant anteaters of varying ages from the Wild Animal Screening Center (CETAS-GO) were used, seven for X-ray exams and two adults for CT exams. The hyoid elements in all the animals were evaluated using the two imaging techniques, and were visualized in the cervical region of C2 to C6, which comprises three paired bones (stylohyoid, epihyoid, ceratohyoid) and one unpaired bone (basihyoid). The presence of air in the oropharynx enabled the assessment of soft tissue structures in this region, such as the epiglottis and the soft palate. CT axial sections are of limited usefulness for evaluating the hyoid bones, but enable assessments of the basihyoid bone and its characteristic V-shape. Thus, to analyze the hyoid region in anteaters based on radiographic and tomographic images, one must keep in mind that the stylohyoid, epihyoid and ceratohyoid bones are situated ventrally to the $\mathrm{C} 2$ to $\mathrm{C} 5$ vertebrae and that the basihyoid at the level of C5-C6 demarcates the transition between the nasopharynx and the trachea. The nasopharynx and oropharynx extend from $\mathrm{C} 1$ to $\mathrm{C} 5$, and the trachea begins at the level of C6.
\end{abstract}

INDEX TERMS: Cervical region, hyoid apparatus, giant anteater, Myrmecophaga tridactyla, oropharynx, radiology, topographical anatomy, trachea, V-shaped bone, xenarthra.

\footnotetext{
${ }^{1}$ Received on July 13, 2016.

Accepted for publication on January 25, 2017.

${ }^{2}$ Setor de Diagnóstico por Imagem, Escola de Veterinária e Zootecnia, Universidade Federal de Goiás (UFG), Campus Samambaia, Cx. Postal 131, Goiânia, G0 74001-970, Brazil. *Corresponding author: naidaborges@yahoo.com.br

${ }^{3}$ Médico veterinário autônomo, Scan Medicina Veterinária Diagnóstica, AOS 4/5, Bloco D, Loja 59, Edifício Pampulha, Brasília, DF 70660-655, Brazil.

${ }^{4}$ Departamento de Medicina Veterinária, Universidade Estadual do Centro-Oeste (Unicentro), Campus Cedeteg, Rua Simeão Carvalho Varela de Sá 3, Vila Carli, Guarapuava, PR 85040-080, Brazil

${ }^{5}$ Hospital Veterinário, Universidade de Rio Verde (UniRV), Fazenda Fonte do Saber, Cx. Postal 104, Rio Verde, GO 75901-970, Brazil.

${ }^{6}$ Médica veterinária autônoma, Rua Guanabara 3745, Bairro São João Bosco, Porto Velho, R0 76803-841, Roraima, Brazil.
}

RESUMO.- [Descrição anatômica da região cervical e aparato hioide em espécimes vivos de tamanduá-bandeira, Mymercophaga tridactyla Linnaeus, 1758.] o Tamanduá-Bandeira possui adaptações anatômicas específicas, devido aos hábitos alimentares de ingestão de formigas e cupins. $\mathrm{O}$ arranjo singular do aparato hioide dos tamanduás é fundamental para a ingestão de alimentos. Sua descrição na literatura é baseada em peças e fósseis, o que dificulta a determinação de detalhes anatômicos existentes em animais vivos. As técnicas de imagem permitem a avaliação da anatomia topográfica dos animais, de maneira não invasiva, e o conhecimento desta é fundamental para o diagnóstico e prognóstico de afecções. 0 objetivo desse 
trabalho foi descrever o contorno ósseo do aparato hioide do tamanduá-bandeira, por meio de imagens radiográficas e tomográficas. Foram utilizados tamanduás-bandeiras provenientes do Centro de Triagem de Animais Silvestres (CETAS-GO), sendo sete, de variadas idades, para os exames radiográficos e dois adultos para os tomográficos. Os elementos hioideos foram avaliados em todos os animais por meio de ambas as técnicas de imagem, sendo visibilizados na região cervical, de $\mathrm{C} 2$ até $\mathrm{C} 6$, composto por três elementos pares (estiloioide, epioide, ceratioide) e um elemento ímpar (basitireoide). A presença de ar na orofaringe permitiu a avaliação das estruturas de tecidos moles desta região, como a epiglote e o palato mole. Os cortes tomográficos axiais têm importância limitada na avaliação dos hioides, mas permitem a avaliação do basitireoide e de seu formato característico (V-bone). Desta forma, para avaliar a região hioidea por meio dos exames radiográficos e tomográficos em tamanduás-bandeira, deve-se considerar que os ossos estiloioide, epioide e ceratioide localizam-se ventral às vértebras $\mathrm{C} 2$ até $\mathrm{C} 5$ e o basitireoide, em $\mathrm{C} 5$-C6, delimita a transição entre a nasofaringe e a traqueia. A orofaringe e a nasofaringe estendem-se de $\mathrm{C} 1 \mathrm{a} \mathrm{C} 5$, e a traqueia inicia-se a partir de $\mathrm{C} 6$.

TERMOS DE INDEXAÇÃO: Região cervical, aparato hioide, tamanduá-bandeira, Mymercophaga tridactyla, anatomia topográfica, orofaringe, radiologia, traqueia, "V-bone", xenarthra.

\section{INTRODUCTION}

The giant anteater (Myrmecophaga tridactyla Linnaeus, 1758 ) is the largest representative of the family Myrmecophagidae. Its feeding habits, which consist mainly of ants and termites, have given this species specific anatomical adaptations that set it apart from other mammals (Chiarello et al. 2008). The International Union for Conservation of Nature (IUCN) classifies Myrmecophaga tridactyla as a vulnerable species (IUCN 2014). The giant anteater belongs to one of the 13 remaining genera of the superorder Xenarthra, a lineage that used to comprise more than 180 genera. Thus, its preservation is important not only from the standpoint of today's fauna but also from that of a historical lineage in South America (Vizcaíno \& Bargo 2014).

Comparative studies have been made of the myology and osteology of the feeding apparatus of the anteater Tamandua mexicana and the giant anteater Myrmecophaga tridactyla (Reiss 1997). In his description of giant anteaters, Naples (1999) states that these animals have a feeding system adapted to their peculiar cranial anatomy, with a long slender tongue that can be projected to a distance greater than the length of the skull to rapidly capture and transfer food to its oral cavity, which is supported by a large, elongated hyoid apparatus. The functions of the hyoid apparatus are to control the airways and to support and maintain the position of the tongue during feeding; it also participates indirectly in the production of sounds (Pérez et al. 2010).

Pérez et al. (2010) formulated hypotheses about the bony elements of the hyoid apparatus in various fossil species of the superorder Xenarthra, seeking answers about the mechanism of tongue movement and the food intake pattern. With the aid of computed tomography, Endo et al. (2007) studied the medial and lateral mandibular movements in a giant anteater carcass, and identified the muscles involved in these movements.

The aforementioned studies detailed the anatomy and unique morphophysiology of the hyoid apparatus of fragments and fossils, which limits the description of details regarding adjacent soft tissues, which are perceptible only in live animals. These findings were reported by Pérez et al. (2010), who stated that an intact hyoid complex is rarely found even in well-preserved fossils. However, Pérez et al. (2000) were able to determine that one of the most significant differences between xenarthrans and other mammals in terms of the anatomy of the hyoid apparatus is the unique shape of the basihyoid bone, which results from the fusion of the basihyoid and thyrohyoid, forming a single $\mathrm{V}$-shaped bone.

The above information clearly points to the need for other means to describe the anatomy of this bony complex, which may be helpful in visualizing soft tissues and other adjacent structures without jeopardizing the survival of these animals, and without the limitations of studies on fragments and fossils. In this regard, imaging studies provide anatomical and functional information to aid the diagnosis and prognosis of diseases (Galvão 2000, Scrivani 2002), and to obtain the best results in the interpretation of imaging studies it is essential to have detailed knowledge about the topographic anatomy of the regions of interest (Antoniazzi et al. 2008).

This article thus proposes to describe the radiographic and tomographic anatomy of the hyoid apparatus and adjacent structures of the anteater giant, as well as to determine the complementarity of the two imaging techniques in describing the anatomical relationships between the structures visualized through these techniques.

\section{MATERIALS AND METHODS}

This study involved seven giant anteaters (Myrmecophaga tridactyla) of both sexes, comprising three adults, two juveniles and two pups. The animals were provided by the Wild Animal Screening Center (CETAS) located in Goiânia, state of Goiás, Brazil. The mission of this center, which belongs to the Brazilian Institute of Environment and Renewable Natural Resources (IBAMA), is to rescue wild fauna and, whenever possible, return them to nature.

The evaluations were performed at the Veterinary Hospital (HV) of the School of Veterinary Medicine and Animal Science (EVZ) of the Federal University of Goiás (UFG), according to the need for clinical and/or surgical treatment of this species. The animals were then X-rayed in the Diagnostic Imaging Department of the HV/EVZ/UFG, and when necessary, were subjected to CT scanning at Scan Medicina Veterinária Diagnóstica, a clinic located in the city of Brasilia, Federal District. The treatments were authorized by the projects Clinical and Surgical Treatment of Wild Animals and Diagnostic Imaging, registered under numbers EV83 and EV-68, respectively, in the Extension and Culture Information System of the Office of the Vice Dean of Extension and Culture (SIEC/PROEC) of UFG.

To reduce the stress caused by handling and transportation, the animals were housed individually in wooden boxes. Upon arrival at the locations where the examinations would be performed, they were anesthetized intramuscularly with $7 \mathrm{mg} / \mathrm{kg}$ of ketamine 
(Ketamina Agener ${ }^{\circledR} 10 \%$, União Química Farmacêutica Nacional $\mathrm{S} / \mathrm{A}$, Brazil) and $0.2 \mathrm{mg} / \mathrm{kg}$ of midazolam (Dormire ${ }^{\circledR} 0.5 \%$, Cristália Produtos Químicos Farmacêuticos Ltda, Brazil). After the exa$\mathrm{ms}$ and other procedures, the animals were returned to CETAS.

The animals were X-rayed using a TUR ${ }^{\circledR} \mathrm{T}-350$ stationary X-ray system with a capacity rating of $600 \mathrm{~mA}$, equipped with a Potter-Bucky grid. Kodak T-MAT X-ray films were used, which were mounted on a $30 \mathrm{~cm} \times 40 \mathrm{~cm}$ rigid chassis equipped with a pair of image intensifiers. A film-focus distance of $90 \mathrm{~cm}$ was used, and the kilovoltage $(\mathrm{kV})$ and milliamperage $(\mathrm{mA})$ were calculated according to the thickness, in centimeters, of the cervical region, varying between $43-58 \mathrm{kV}$ and $4-10 \mathrm{mAs}$. The radiographic films were identified individually and processed in a Vision Line ${ }^{\circledR}$ LX-2 automatic processor (Lotus, Brazil).

The hyoid apparatus was observed using right-side laterolateral (LL) and ventrodorsal (VD) radiographic projections of the cervical and cervical thoracic region. The radiographs were analyzed according to the anatomical descriptions formulated by Naples (1999), which were used to identify the four characteristic hyoid elements of the giant anteater.

CT scanning was performed on two adults anteaters, using an ELSCINT $^{\circledR}$ SeleCT SP single channel helical CT scanner (Elscint Ltd, Haifa, Israel). The animals were placed in a supine position on the examination table, with the forelimbs oriented cranially and the hind limbs caudally. CT scans were performed on the axial plane with in $5 \mathrm{~mm}$ thick scan slices, starting at the base of the skull and extending to the first thoracic vertebra, without gaps. Scanning was performed at $120 \mathrm{kVp}$ and $150 \mathrm{~mA}$. The images were analyzed using OSIRIX software, with 3D reconstruction and a window for 2D reconstruction of bone tissue.
After the analysis of radiographic and tomographic images, illustrations were prepared to better understand the topographical anatomy of the hyoid region. The images were prepared by veterinary doctor and coauthor Larissa H.E. Rüncos.

Descriptions of the exams were made based on anatomical studies of domestic mammals (Getty 1986, Dyce et al. 2010, Budras et al. 2007) and of corpses of giant anteaters and other mammals of the superorder Xenarthra (Reiss 1997, Naples 1999, Pérez et al. 2010).

\section{RESULTS}

All the hyoid elements were identified in the radiographs in laterolateral projection (Fig.1A), which revealed overlapping of the paired elements. The longest of all the elements was the stylohyoid, which extended from C2 to C5. Its cranial portion was free, without correlation to the bone structures of the skull, and its caudal portion was articulated with the epihyoid. The epihyoid was elongated in shape, about half the size of the stylohyoid, and articulated caudally with the ceratohyoid. The smallest of all the elements was the ceratohyoid, with a triangular shape, and articulated caudomedially with the basihyoid bone. The basihyoid was the most characteristic of the hyoid elements, with a ventral portion and two vertical caudocranially oriented stems. The nasopharynx was long, extending ventrally to the cervical vertebrae ( $\mathrm{C} 1$ to $\mathrm{C} 5$ ). Its caudal edge was defined by the basihyoid bone and laryngeal cartilage. The laryngeal cartilage of the adult animals was mineralized, facilitating its radiographic visualization.
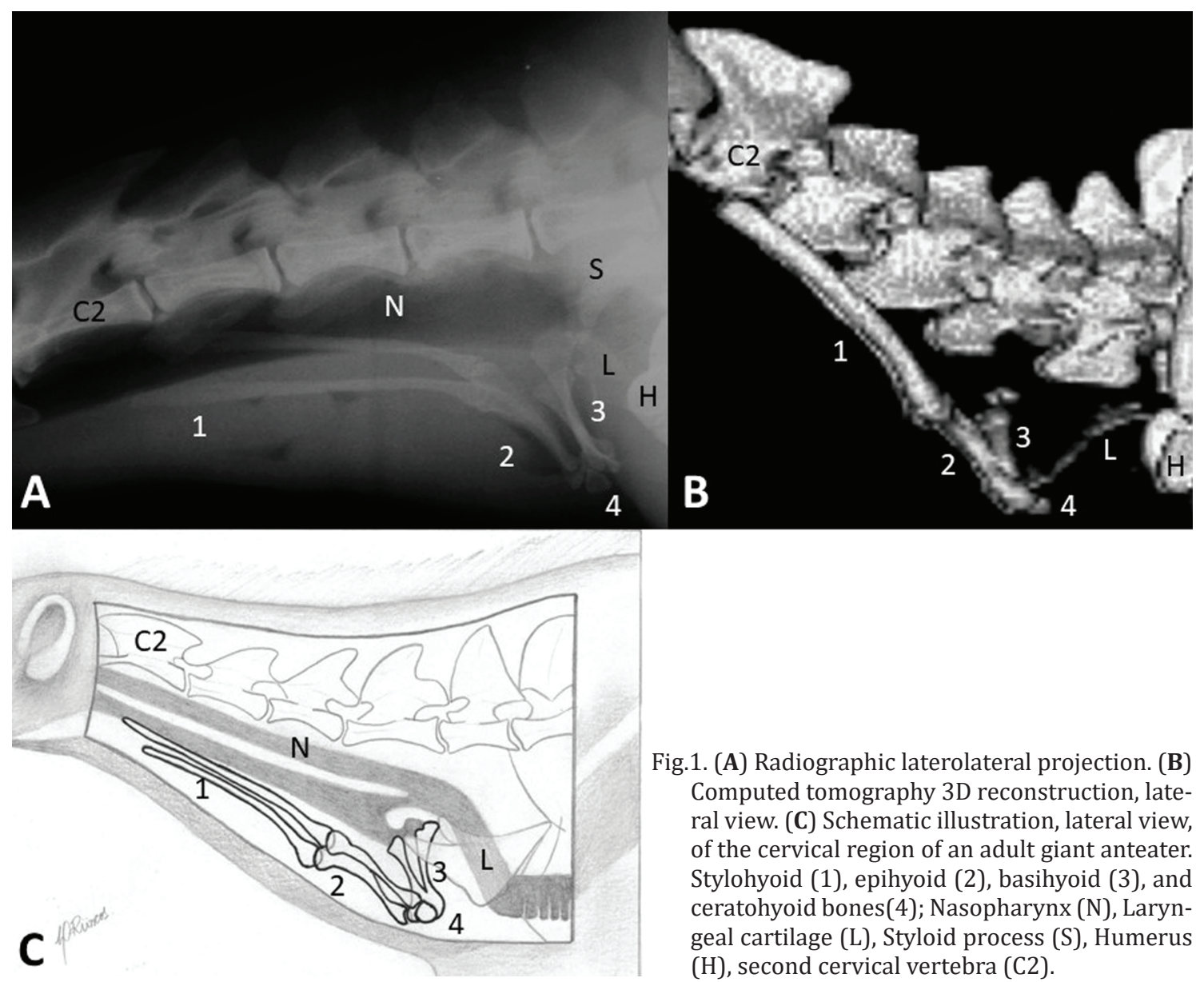

Fig.1. (A) Radiographic laterolateral projection. (B) Computed tomography 3D reconstruction, lateral view. (C) Schematic illustration, lateral view, of the cervical region of an adult giant anteater. Stylohyoid (1), epihyoid (2), basihyoid (3), and ceratohyoid bones(4); Nasopharynx (N), Laryngeal cartilage (L), Styloid process (S), Humerus $(\mathrm{H})$, second cervical vertebra (C2). 
Similar to radiography in laterolateral projection, the 3D tomographic reconstruction in side view (Fig.1B) also enabled the assessment of the hyoid elements, with overlapping of the paired elements. However, the other soft tissue structures were not visible in the tomographic reconstruction and the laryngeal cartilage was visible in less detail than in the radiographs.

To facilitate the description and identification of the bone structures that make up the hyoid apparatus and its relationship with the adjacent soft tissues, a schematic illustration was produced (Fig.1C), associating the radiographic and tomographic images.

In the radiograph in ventrodorsal projection (Fig.2A), the stylohyoid and epihyoid bones were visualized as paired elements, with the stylohyoids parallel to the spine and the epihyoids overlapping the C4 and C5 vertebrae. The ceratohyoids were not identified in this projection, and the basihyoid was partially visible, overlapping the fifth cervical vertebra. In this projection, the basihyoid delimited the nasopharynx cranially, and was partially visible as a less opaque area in the cranial vertebral bodies, and caudally to the trachea, visualized as a tubular radiolucent area overlapping the cervical vertebrae $\mathrm{C} 6$ and $\mathrm{C} 7$.

The 3D tomographic reconstruction in ventrodorsal view (Fig.2B) enabled not only an evaluation of the stylohyoids and epihyoids but also identification of the ceratohyoids, located laterally to the basihyoid, without overlapping the vertebral bodies. The basihyoid was also properly identified. A schematic illustration (Fig.2C) was also produced to evaluate the structures that make up the ventrodorsal view, in order to better identify the relationship of the hyoid bones.

In patients with aerophagia, the radiographic details (Fig.3A) enabled an efficient evaluation due to the radiolucent, negative contrast of the oropharynx, soft palate and epiglottis. The oropharynx was identified ventrally to the nasopharynx, delimited dorsally by the soft palate and caudally by the epiglottis. The comma-like shaped epiglottis

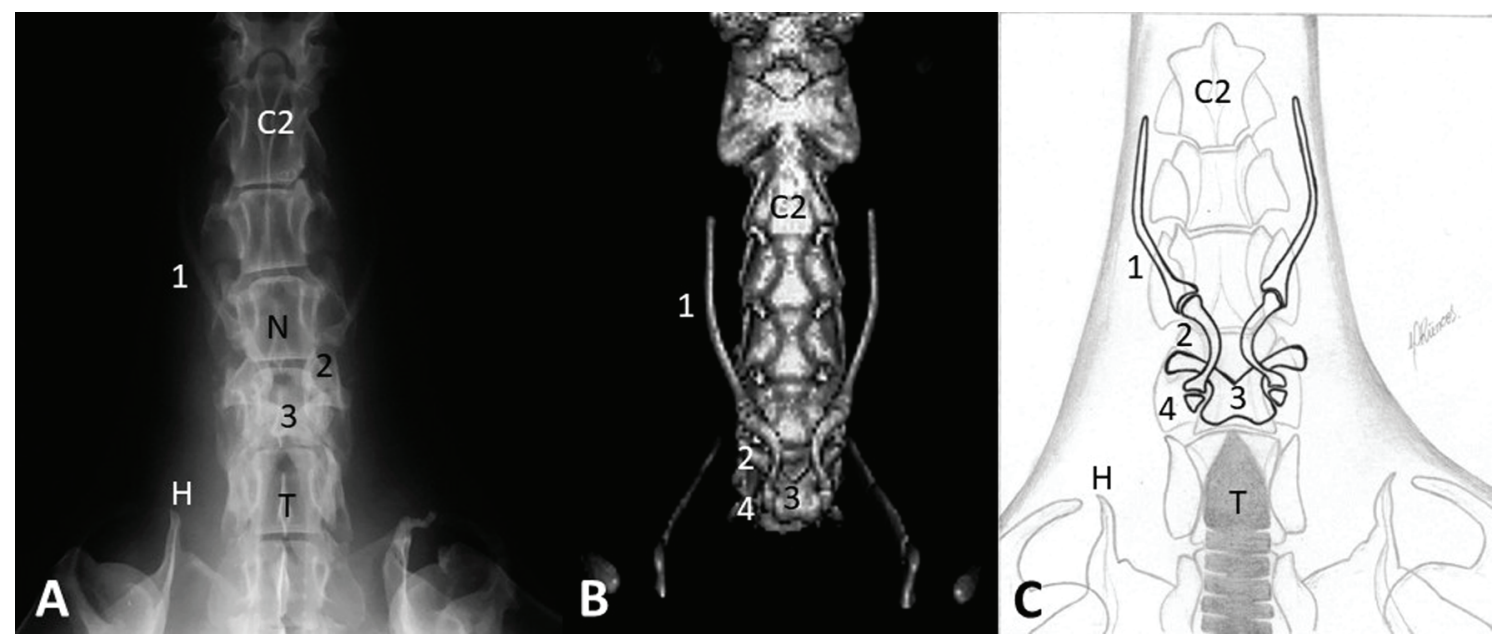

Fig.2. (A) Radiographic ventrodorsal projection. (B) Computed tomography 3D reconstruction, ventrodorsal view. (C) Schematic illustration, ventrodorsal view of the cervical region of an adult giant anteater. Stylohyoid (1), epihyoid (2), basihyoid (3), and ceratohyoid (4) bones; Nasopharynx (N), Trachea (T), second cervical vertebra (C2), Humeral process (H).

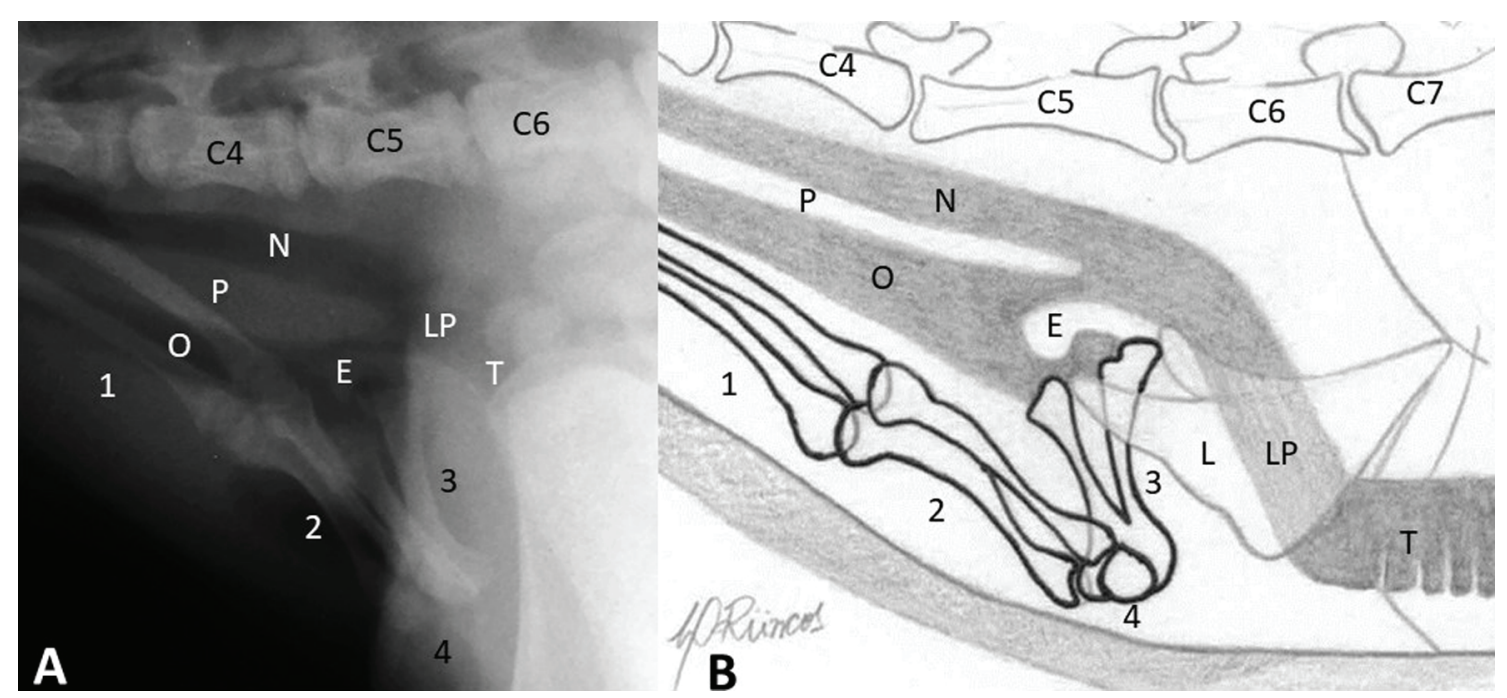

Fig.3. (A) Detail of the caudal cervical region of a young giant anteater, radiographic laterolateral projection. (B) Schematic illustration of this region. Oropharynx (O), Nasopharynx (N), Palate (P), Epiglottis (E), Laryngeal cartilage (L), Laryngopharynx (LP), Trachea (T); Epihyoid (1), Stylohyoid (2), Basihyoid (3), Ceratohyoid bones (4); Cervical vertebrae (C4 to C7). 


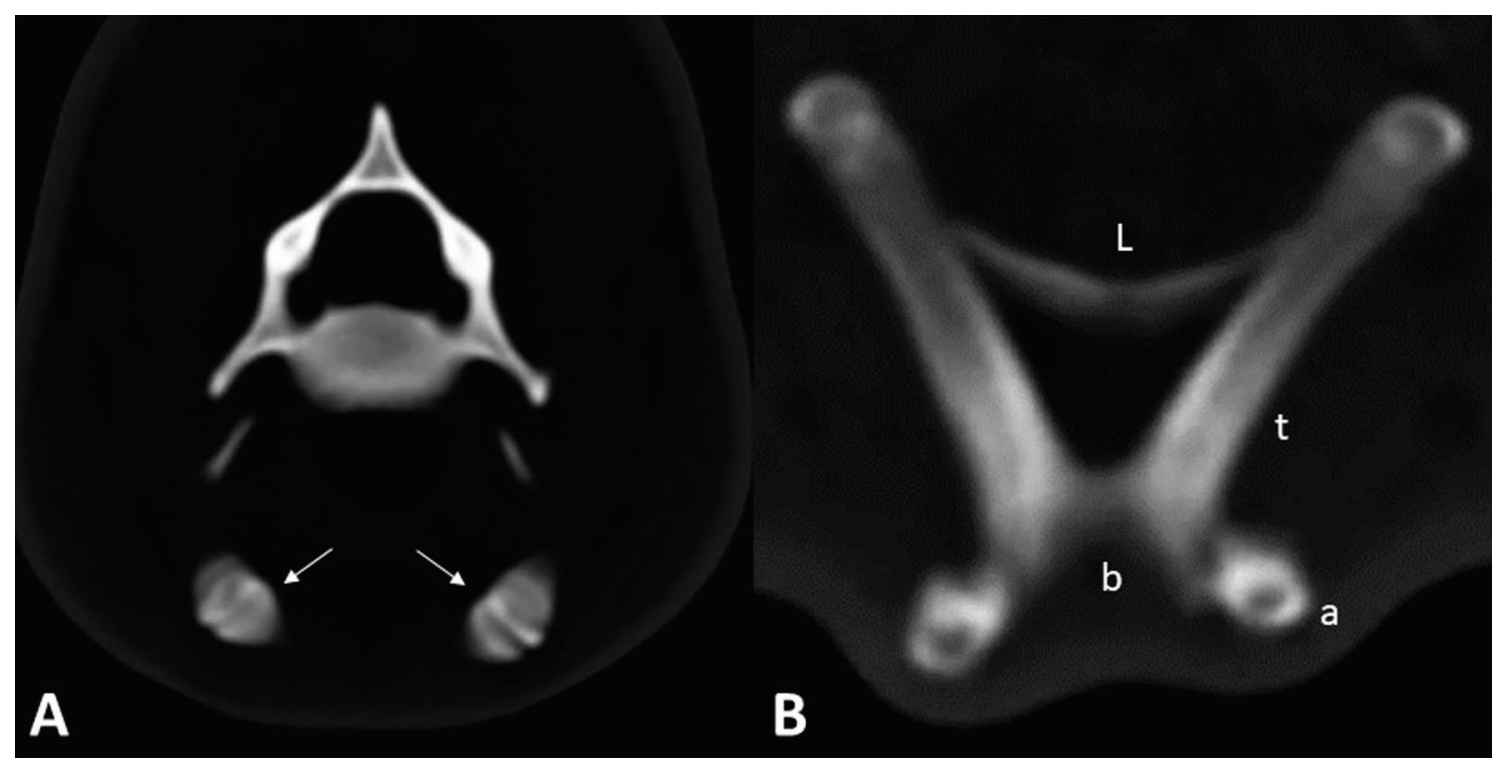

Fig.4. CT axial sections of the cervical region of an adult giant anteater. (A) Articulation between the stylohyoid and epihyoid bones (arrows), seen ventrally to the sixth cervical vertebra. (B) Basihyoid bone, with its characteristic V shape. Laryngeal cartilage (L); anterior projection (a), basihyoid portion (b), thyrohyoid portion of basihyoid bone (t).

was visualized dorsally to the basihyoid. The trachea started caudally to the epiglottis and laryngeal cartilage, at the height of the sixth cervical vertebra. All the structures described in this region were highlighted in a schematic illustration (Fig.3B).

The axial tomographic sections were not suitable for evaluating the hyoid bones, because of the sagittal orientation of these bones to the scan axis. However, they were useful to identify and evaluate the articulations between the hyoid elements (Fig.4A), and also enabled the identification of the $\mathrm{V}$-shape of the basihyoid bone and of anatomical details (Fig.4B).

\section{DISCUSSION}

In evaluating the hyoid apparatus of giant anteaters based on radiographic and tomographic imaging, special attention should focus on the topographic localization of this apparatus because it occupies the entire cervical region and should therefore be examined from $\mathrm{C} 1$ to $\mathrm{C} 6$. This differs significantly from domestic animals, whose hyoid elements are situated ventrally from the base of the skull to the first cervical vertebra, as described by Weissengruber et al. (2002), Solano \& Brawer (2004), Takada et al. (2009) and Dyce et al. (2010). Big cats also differ from Xenarthra species, since their hyoid elements are located at the level of C3 to C5 (Weissengruber et al. 2002). This anatomical feature of anteaters is important, because imaging studies of the craniocervical region may result in a partial assessment of the hyoid elements and adjacent soft tissues, thus leading to misinterpretations.

According to Naples (1999), this elongation of the hyoid apparatus is mainly due to the elongation of the stylohyoid and epihyoid, causing the bones of the hyoid apparatus of anteaters to present a caudoventral orientation relative to the skull. This differentiates them from other mammals, whose hyoid apparatus presents anterior orientation, and even from other xenarthrans such as sloths, which have anteroventral orientation (Naples 1986). This orientation, which differs from that of most species, was found in imaging studies performed on anteaters in this study, and is an additional factor to be considered by clinicians, surgeons and radiologists when evaluating the hyoid apparatus and cervical region of the giant anteater.

Stylohyoid ligaments with the skull were not visible in the radiographic or the tomographic images. However, in giant anteaters, the stylohyoids attach to the occipital protuberance through the stylo-occipital muscle (Naples 1999), unlike other species such as dogs, in which the hyoid inserts in the mastoid process of the temporal bone through its cartilaginous portion, the tympanohyoid, located in the terminal portion of the stylohyoid (Budras et al. 2007). The stylohyoids are attached through muscle structures, which are not visible in radiological examinations but must be considered in the case of alterations in this topography, such as calcifications, masses and ruptures.

The oropharynx, soft palate and nasopharynx of the giant anteater are also longer than those of other mammals, and similar to Tamandua mexicana (Reiss 1997), extending to the transition between the fifth and sixth cervical vertebrae, where the laryngopharynx begins. This great extension of the pharyngeal tube is also accompanied by elongation of the pharyngeal wall muscles and the long length of the hyoid apparatus (Naples 1999). These anatomical features are necessary to contain the extremely elongated tongue (Reiss 1997, Naples 1999). It is crucial to understand these anatomical details in order to assess this region in imaging studies, so that one can avoid, for instance, incorrectly identifying the nasopharynx as the cervical portion of the trachea. The nasopharynx was identified in the radiographic examination of the anteaters as a radiolucent tube occupying the entire cervical length, much like the cervical trachea in domesticated mammal species. 
Given the extensive topography of the pharyngeal elements, the beginning of the cervical trachea was identified at the level of the sixth cervical vertebra immediately caudal to the basihyoid. In this respect, it differs from other domesticated mammals such as dogs and cattle, in which the trachea begins at the level of C2 (Budras et al 2007, Evans \& de Lahunta 2013). Therefore, in this study, the laterolateral and ventrodorsal cervical radiographs identifying the exact localization of the trachea will be extremely useful in surgical and anesthetic procedures, as well as in the choice of the proper tube length for endotracheal intubation. Brainard et al. (2008), who described the difficulty of performing a tracheotomy and inserting an endotracheal tube in a dead giant anteater, mentioned the limitations of surgical and anesthetic procedures involving the trachea, because its palpation is hampered by the bony structures at the entrance of the thorax. Brainard et al. (2008) observations underscore the importance of radiology exams for the topographic identification of the trachea, pharyngeal elements and other structures that were identified in this study of live giant anteaters.

Radiolucent lines were visible among the hyoid elements, in both the radiographic and tomographic images. These images correspond to synovial joints that Naples (1999) and Pérez et al. (2010) identified between the hyoid bones in giant anteaters. These joints allow for variations in the length of the hyoid elements, which can alter its total length by about $35 \%$, from fully contracted to fully extended. This differs from many other mammals, in which the hyoid elements are fused or ossified, without joints, although some carnivores (Takada et al. 2009), felids (Weissengruber et al. 2002) and cattle (Budras 2007) present these synovial joints between the hyoid elements. In other adult xenarthrans (Tamandua mexicana (Reiss 1997) and sloths of the genera Bradypus and Choloepus (Naples 1986) that have been studied, these elements are fused, but in giant anteaters these elements have mobility, even in older animals (Naples 1999). It is also important to emphasize the importance of knowledge about these joints, to avoid mistaking them for fractures of the hyoid elements, which may occur in cases of trauma affecting the cervical region.

The basihyoid bone was identified as a single wide structure, as described for carcasses by Naples (1999) and Pérez et al. (2000), corresponding to the fusion of the basihyoid and thyrohyoid. This is a variation characteristic of the hyoid apparatus in Xenarthrans (Pérez et al. 2010), which was clearly identified in both examinations. The radiographic examination proved satisfactory for identifying most of the structures of the hyoid apparatus of the giant anteater. However, some structures were not visible due to the effect of overlapping with the cervical vertebrae. The basihyoid was the element most affected in this assessment, since it was not possible to visualize its V-shape due to this overlap, especially in ventrodorsal projection. However, in this projection, this element demarcates the transition between the nasopharynx and the trachea, so it is recommended for surgical or anesthetic procedures that require the identification and localization of the trachea.

Computed axial tomography allows for better visualiza- tion of the basihyoid and its anatomical details, because it avoids overlapping, enabling the identification of its vertical portions (originating from the thyrohyoid), the ventral portion (originating from the basihyoid) and the anterior projections, which articulate with the ceratohyoid, similar to what Pérez et al. (2010) described in carcasses and fossils. The 3D reconstruction revealed the same structures as those observed in the radiographs, but allowed for a better analysis of the spatial relationship of the bony structures, particularly in the ventrodorsal projection, which facilitated the identification of the basihyoid and ceratohyoid. This is in agreement with Leblanc \& Daniel (2007) and Da Costa \& Samii (2010), who stated that computed tomography is a better diagnostic tool than radiography for the evaluation of complex structures. However, in this study, we found that tomography did not allow for a proper evaluation of the nasopharynx, oropharynx, palate, epiglottis, laryngopharynx and trachea.

The anatomical and topographical study of the hyoid region in the giant anteater by means of radiography and computed tomography enabled a detailed visualization of the bony structures, joints and adjacent soft tissues of the hyoid apparatus. The 3D tomographic reconstruction allowed for the selection and isolation of specific regions, showing details of bones that are not visible on radiographs due to overlapping. The radiographs provided information about the adjacent soft tissues, which were not visible in the CT scans. Both radiology and tomography were effective for evaluating this region, and are complementary techniques for assessing the hyoid region.

\section{CONCLUSIONS}

When evaluating the hyoid apparatus and adjacent structures in giant anteaters by means of radiographic and tomographic imaging, it should be kept in mind that:

(1) The stylohyoid, epihyoid and ceratohyoid bones are situated ventrally to the $\mathrm{C} 2$ to $\mathrm{C} 5$ vertebrae;

(2) The basihyoid is located ventrally to C5-C6 and demarcates the transition between the nasopharynx and trachea in ventrodorsal projection;

(3) The oropharynx and nasopharynx extend from C1 to $\mathrm{C} 5$, and the trachea begins at $\mathrm{C} 6$.

Acknowledgments.- The authors thank the Wild Animal Screening Center (CETAS) of the Brazilian Institute of Environment and Renewable Natural Resources (IBAMA) in Goiânia, Goiás, Brazil, for providing the animals used in this research.

\section{REFERENCES}

Antoniazzi M.C.C., Carvalho P.L. \& Koide C.H. 2008. Importância do conhecimento da anatomia radiográfica para a interpretação de patologias ósseas. Revta Gaúcha Odontol. 56:195-199.

Brainard B.M., Newton A., Hinshaw K.C. \& Klide A.M. 2008.Tracheostomy in the Giant Anteater (Myrmecophaga tridactyla). J. Zoo Wildl. Med. 39(4):655-658.

Budras K.D., Mccarthy P.H., Horowitz A. \& Berg R. 2007. Anatomy of the dog. 5th ed. Schlütersche Verlagsgesellschaft and Co., Hannover. 216p.

Chiarello A.G., Aguiar L.M.S., Cerqueira R., Melo F.R., Rodrigues F.H.G. \& Silva V.M.F. 2008. Mamíferos. In: Machado A.B.M., Drummond G.M. \& Paglia A.P. (Eds), Livro Vermelho da Fauna Brasileira Ameaçada de Extinção. Fundação Biodiversitas, Belo Horizonte. 
Da Costa R.C. \& Samii V.F. 2010. Advanced imaging of the spine in small animals. Vet. Clin. N. Am., Small Anim. Pract. 40:765-790.

Dyce K.M., Sack K.O. \& Wensing C.J.G. 2010. Tratado de Anatomia Veterinária. $4^{\mathrm{a}}$ ed Elsevier, Rio de Janeiro. $840 \mathrm{p}$.

Endo H., Niizawa N., Komiya T., Kawada S., Kimura J., Itou T., Koie H. \& Sakai T. 2007. Three-dimensional CT examination of mastication system in the giant anteater. Zool. Sci. 24:1005-1011.

Evans H.E. \& De Lahunta A. 2013. Miller's Anatomy of the Dog. 3rd ed. Elsevier Saunders, 872p.

Galvão P.B.A. 2000. Tecnologia e medicina: imagens médicas e a relação médico-paciente. Revta Bioet. 8(1):32-44.

Getty R. 1986. Anatomia dos Animais Domésticos. 5a ed Guanabara Koogan, Rio de Janeiro. 2052p.

Leblanc A.K. \& Daniel G.B. 2007. Advanced imaging for veterinary cancer patients. Vet. Clin. N. Am., Small Anim. Pract. 37:1059-1077.

IUCN 2014. IUCN Red List of Threatened Species. International Union for Conservation of Nature and Natural Resources. Avaliable from <www. iucnredlist.org>

Naples V.L. 1986. The Morphology and Function of the Hyoid Region in the Tree Sloths, Bradypus and Choloepus. J. Mammal. 67(4):712-724.

Naples V.L. 1999. Morphology, evolution and function of feeding in the giant anteater (Myrmecophaga tridactyla). J. Zool. 249:19-41.
Pérez L.M., Scillato-Yané G.J. \& Vizcaíno S.F. 2000. Estudio Morfofuncional del aparato hioideo de Gliptodon cf. Clavipes owen (Cingulata: Glyptodontidae). Ameghiniana, 37(3):293-299.

Pérez L.M., Toledo N., De Iuliis G., Bargo M.S. \& Vizcaíno S.F. 2010. Morphology and function of the hyoid apparatus of fossil xenarthrans (Mammalia). J. Morphol. 271:1119-1133.

Reiss K.Z. 1997. Myology of the feeding apparatus of myrmecophagid anteaters (xenarthra: myrmecophagidae). J. Mamm. Evol. 4(2):87-117.

Scrivani P.V. 2002. Accessing diagnostic accuracy in veterinary imaging. Vet. Radiol. Ultrasound 5:442-448.

Solano M. \& Brawer R.S. 2004. CT of the equine head: Technical considerations, anatomical guide, and selected diseases. Clin. Tech. Equine Pract. 3:374-388.

Takada Y., Izumi M. \& Gotoh K. 2009. Comparative Anatomy of the Hyoid Apparatus of Carnivores. Mammal Study 34(4):213-218.

Vizcaíno S.F. \& Bargo M.S. 2014. Loss of ancient diversity of xenarthrans and the value of protecting extant armadillos, sloths and anteaters. Edentata, 15:27-38.

Weissengruber G.E., Forstenpointner G., Peters G., Kubber-Heiss A. \& Fitch W.T. 2002. Hyoid apparatus and pharynx in the lion (Panthera leo), jaguar (Panthera onca), tiger (Panthera tigris), cheetah (Acinonyx jubatus) and domestic cat (Felis silvestris f. catus). J. Anat. 201:195-209. 